\title{
A COMPARATIVE STUDY OF ISLAMIC AND SOUTH AFRICAN LAW ON LIVING AND CADAVERIC ORGAN DONATIONS: CONSENSUS AND DIVERGENCE*
}

\author{
SS Nadvi \\ MBChB FCS(SA) (Neuro) LLM MD \\ Lecturer, Department of Neurosurgery, UKZN \\ M Osman-Hyder \\ LLB LLM \\ Lecturer, School of Law, UKZN
}

\section{SUMMARY}

Religion plays a pivotal role in people's attitude to organ donation. Generally, practising Muslims (adherents of the Islamic faith) are unlikely to consent to organ donation because they believe it is not in keeping with the tenets of Islamic law (Sharīah). Although there is a wealth of information on organ donation with reference to both South African and Islamic law, there has not been a study comparing the two sets of laws. The purpose of this article is to develop the literature on living and cadaveric organ donation by drawing a comparison between Islamic law and South African law on this issue. Apart from a few minor differences inherent in each set of laws, there is a startling consensus in South African law and Sunni (mainstream) Islamic law ${ }^{1}$ on the issue of organ donation. ${ }^{2}$ This research is also significant in that it provides legal and medical professionals, academics and practitioners with an informed position from which to advise clients and/or patients. This may in turn raise awareness among clients and/or patients, which could result in a desirable increase in organ donation rates among Muslims in South Africa. This article makes a number of recommendations in this regard.

\footnotetext{
This article is based on SS Nadvi's LLM dissertation entitled Living and Cadaveric Organ Donations: A Comparative Study of Islamic and South African Law - Consensus and Divergence. We are grateful to Professor Magda Slabbert, Professor of Jurisprudence at UNISA for encouraging us to publish an article based on the dissertation.

1 Muslims can be divided into two main groups: a majority of Sunnī Muslims, and a minority of Shī ah Muslims. Iran is the only Shī ah Muslim country.

2 Shì ah Islamic scholars hold a more liberal view and allow for the sale of organs in Iran through a state-run compensated organ procurement system.
} 


\section{INTRODUCTION AND BACKGROUND}

Transplantation is necessary when a patient's organ has failed or has been damaged by disease or injury; ${ }^{3}$ organ transplantation remains among the most effective methods to treat a patient with end-stage organ disease. ${ }^{4}$ Apart from saving lives, it drastically improves the quality of life of persons and is also the most cost-effective means of treatment. ${ }^{5}$

Organ donation is the process of surgically removing an organ or tissue from one person (the organ donor) and placing it into another person (the recipient). ${ }^{6}$ This process is also referred to where the donor is alive. ${ }^{7}$ Cadaveric organ donations occur once the donor is dead. ${ }^{8}$ Organ transplantation in South Africa is regulated by the National Health Act $^{9}$ $(\mathrm{NHA})$ and its regulations. ${ }^{10}$ "Organ", as defined by the NHA, means any part of the human body adapted by its structure to perform any particular vital function, including the eye and its accessories, but does not include skin and appendages, flesh, bone, bone marrow, body fluids, blood or a gamete. ${ }^{11}$ Although "organ" is separately defined, it is also included in the definition of "tissue". ${ }^{12}$

The biggest limitation to organ transplantation, both in South Africa and globally, is the dire shortage of organs. ${ }^{13}$ For example, in 2016, only 249 kidney transplants were performed in South Africa, with 512 organ transplants being performed in total, and this included corneal transplants. Considering that there are approximately 6000 people awaiting kidney transplants, and that only 249 kidney transplants were performed in 2016, it is apparent that the number of organ transplants being performed in South Africa is woefully inadequate. ${ }^{14}$

The root cause of the shortage of organs in South Africa is the reluctance of people to bequeath their organs upon death, to donate an organ while still alive (living donation by a related or non-related living donor), or to consent

3 Agrawal "Organ Donation and Transplantation" https://my.clevelandclinic.org/health/articles/ 11750-organ-donation-transplantation (accessed 2019-05-29).

4 Miller "Organ Donation and Transplantation in South Africa: An Update" 2013 31(6) CME

220-222; Etheridge, Turner and Kahn "Public Attitudes to Organ Donation Among a Sample of Urban-Dwelling South African Adults: A 2012 Study" 2013 27(5) Clinical Transplantation 684-692.

5 Sparaco “Increasing Organ Donation: Is Presumed Consent the Answer?" 2017 6(1) Transplantation News 5.

6 Agrawal https://my.clevelandclinic.org/health/articles/11750-organ-donation-transplantation.

7 Blumenthal "The Living Donation Process" https://www.organdonor.gov/about/process/ living-donation.html (accessed 2019-05-29).

Ibid.

61 of 2003.

GG 35099 of 2012-03-02.

National Health Act 61 of 2003. Definitions.

12 Mcquoid-Mason and Dada "Tissue Transplantation and the National Health Act" 2006 24(3) CME 128-130.

13 Sparaco 2017 Transplantation News 5; Etheridge et al 2013 Clinical Transplantation 684-692.

14 Nicholls "Organ Donation Foundation of South Africa, Transplant Statistics, South Africa Organ Donor Foundation" http://www.odf.org.za/ info and faq-s/statistics.html (accessed 2019-03-14). 
to the donation of an organ of a deceased family member (cadaveric organ donation). The question of organ donation and transplantation most commonly arises when a family loses a loved one - a time when there is deep emotional conflict and a sense of loss. ${ }^{15}$ The consent rates, and consequently the number of organ transplants taking place in South Africa, are steadily declining. ${ }^{16}$ There are a myriad reasons for this decline - lack of awareness, ignorance, fallacies and myths. ${ }^{17}$ Certain categories of people in South Africa are particularly reluctant to consent to organ donation, including people with strong religious beliefs. ${ }^{18}$

Because practising Muslims (adherents of the Islamic faith) regard Islamic law as being immutable and God-ordained, ${ }^{19}$ they are hesitant or are unlikely to consent to organ donation as they believe it is not in keeping with the tenets of Islamic law. While Islamic law may be in accordance with South African law, Muslims are hesitant or are unlikely to consent to organ donation owing to their mistaken belief that it is not in keeping with Islamic law. ${ }^{20}$ However, there has, as yet been no study comparing Islamic law and South African law with regard to living and cadaveric organ donation.

Two prominent scholars have addressed the issue of organ donation in South Africa. ${ }^{21}$ Ebrahim has conducted research and written exhaustively on a wide range of biomedical issues affecting Muslims in South Africa. ${ }^{22}$ More pertinent to this study, Ebrahim has written extensively on Islamic law and organ donation. ${ }^{23}$ However, he writes from an Islamic law perspective,

15 Ibid.

16 Etheridge, Turner and Kahn "Attitudes to Organ Donation Among Some Urban South African Populations Remain Unchanged: A Cross-Sectional Study (1993-2013)" 2014 184(2) SAMJ 135-137; Etheridge et al 2013 Clinical Transplantation 684-692; Van Heerden and Du Plessis "Where Do Organs Come From" 2016 5(1) Transplantation News 6-7; Thompson "Organ Donation in South Africa: A Call to Action" 2017 33(2) SAMJ 36-37.

17 Ibid.

18 Blignaut "More People Than Expected in Marginalized Communities Know About Organ Donation" 2017 6(2) Transplantation News 2; Dimo "Organ Donation Behaviour: Debates Amongst Black South African" 2018 16(3) Gender and Behaviour 12200-12210; Mphore "Obliviousness, Not Disease, Is What Kills the Nation" 2016 15(3) Transplantation News 6; Thompson 2017 SAMJ 36-37.

19 Ibid.

20 Sheikh "Shariah: Law and Ethics of Organ Donation in Islam" 2017 13(2) J Int L Islamic L 30-44; Thompson 2017 SAMJ 36-37.

21 For the purposes of this article, the focus is on the South African scholars. There are scholars who address this topic in other parts of the globe.

22 Ebrahim Islam and Vaccination (2013) 82; Ebrahim Biomedical Issues: Islamic Perspective (1988) 164; Ebrahim Reproductive Health and Islamic Values: Ethical and Legal Insights (2011) 107; Ebrahim Intensive Care Unit (ICU) Ethical Dilemmas: Guidelines for Muslim Families (2014) 60; Ebrahim, Hoosen and Hathout Death and Dying: Advising Patient and Family (1995) 21; Ebrahim, Randeree and Vawda Ethics of Medical Research: Some Islamic Considerations (1994) 13; Ebrahim "Euthanasia (Qatl al - alma)" 200739 Journal of the Islamic Medical Association of North America 10-13. Professor Abul Fadl Mohsin Ebrahim is an emeritus Professor of Islamic Law at the University of KwaZulu-Natal.

23 Ebrahim Shariah and Organ Transplants (1989) 67; Ebrahim "Organ Transplantation: Contemporary Sunni Muslims Legal and Ethical Perspectives" 1995 9(34) Bioethics 291-302; Ebrahim "Islamic Perspective on Brain Death and Organ Transplantation: Current Issues and Challenges" in Bagheri and Alali (eds) Islamic Bioethics (2017) 4; Ebrahim Organ Transplantation: Contemporary Islamic Legal and Ethical Perspectives (1988) 146; Ebrahim "The Living Will (Wasiyat Al-Hayy) A Study of its Legality in the Light of Islamic Jurisprudence" 200019 Med Law 147-160. 
without reference to South African legislation. On the other hand, Slabbert has written extensively on organ donation and South African law, with little or no reference to Islamic law. ${ }^{24}$ This study, therefore, attempts to close a gap in the literature through a comparative study of Islamic and South African law regarding organ donation and the bequest of organs, paving the way for better and more informed advice to the community.

This article commences by explaining the South African law on organ donation and includes a discussion on the opt-in and opt-out systems. This is followed by an explanation of the Islamic law position. A comparative analysis of the two systems is then made, followed by some concluding remarks and recommendations.

\section{SOUTH AFRICAN LAW AND ORGAN DONATION}

Organ transplantation in South Africa is regulated by the $\mathrm{NHA}^{25}$ and its regulations, namely the Regulations Regarding the General Control of Human Bodies, Tissue, Blood, Blood Products and Gametes. ${ }^{26}$ The NHA replaced the Human Tissue Act, which was repealed on 1 March 2012. ${ }^{27}$ Chapter 8 of the NHA deals specifically with aspects of organ donation. For the purposes of this study, the term "organ" refers to any solid vital organ for example, the kidney, liver, or heart. The regulations provide that an organ may be removed from a living person only with the written consent of the donor, if he or she is over 18 years of age, or by the parents or guardians of donors under 18 years of age. ${ }^{28}$ In terms of the Act, persons under the age of 18 years may not donate tissue that is not replaceable by natural processes. ${ }^{29}$

Section 58 of the Act deals with the institutions that may perform transplants and the authorisations required. ${ }^{30}$ Section 60 of the Act deals with issues of payment for organs and is very specific. It is an offence for an organ donor to receive financial or other reward for organ donation, except for reimbursement of reasonable costs incurred (for example, travel costs and medical bills). ${ }^{31}$ It is also an offence to sell or trade in organs, except as provided for in the Act. A person convicted of either of these offences may be fined or imprisoned for up to five years or both. ${ }^{32}$ However, a healthcare provider (transplant doctor) registered with a statutory health professional council may receive remuneration for any professional service rendered. ${ }^{33}$ According to the Act, it is illegal to transplant a human organ into a person who is not a South African citizen or permanent resident without the

24 Professor Magda Slabbert is a Professor of Jurisprudence at the University of South Africa and is the leading expert on organ donation in South African law.

25 National Health Act 61 of 2003.

26 GG 35099 of 2012-03-02.

27 Human Tissue Act 65 of 1983.

28 GM R180 in GG 33099 of 2012-03-02.

S 56(2) of the NHA.

$S 58$ of the NHA.

$\mathrm{S} 60(4)$ of the NHA.

$\mathrm{S} 60(5)$ of the NHA.

S 60(3) of the NHA. 
Minister's written authorisation. ${ }^{34}$ Even if a non-South-African or nonpermanent-resident potential donor is genuinely related to the South African recipient, ministerial consent is still required. In genuine cases, it is likely that the Minister will consent. ${ }^{35}$ Doctors who transplant organs into non-South African citizens or permanent residents without ministerial consent, as occurred in the kidney organ-trafficking saga in Durban (discussed below), or who charge a fee for a human organ, as opposed to a fee for professional services, are guilty of an offence and on conviction may be subject to a fine or imprisonment of up to five years or both. ${ }^{36}$

In an important development, the NHA defines death as "brain death". ${ }^{37}$ The regulations provide that in the case of organ transplantation, the death of the deceased has to be determined by two doctors, one of whom must have been qualified for at least five years, and neither of whom may be members of the transplant team. ${ }^{38}$ Where a deceased has not prohibited organ donation while still alive, or has not bequeathed organs while alive, the Act provides a specific order for relatives to consent to organ donation namely, the spouse, partner, major child, parent, guardian, major brother or major sister. ${ }^{39}$

Under the NHA, persons competent to make a will may donate their organ/s in a will or document signed by them and two competent witnesses, or in an oral statement in the presence of two competent witnesses. ${ }^{40}$ Persons have to be over the age of 16 years in order to be regarded as competent to make a will. ${ }^{41}$ Competent witnesses must be older than 14 years. ${ }^{42}$ The bequest of organs in a will, document or statement must be carried out in the prescribed manner, and the donee (recipient) determined in accordance with the prescribed procedure. ${ }^{43}$ Where no specific institution or donee is named, the regulations stipulate that the institution in the appropriate category that is nearest to the place where the donor's body is kept shall be deemed to be the donee. ${ }^{44}$ Also, the regulations stipulate that if the donation is made to a specific recipient who is not within easy reach at the time and place of the donor's death, the institution in the appropriate category that is nearest to the place of the donor's death shall be deemed to be the donee. ${ }^{45}$ With regard to conflicting donations, effect is to be given to the donation made last. ${ }^{46}$ Donation of organs in a will or document can be revoked by intentional destruction of the will or document, or by drawing up a

$34 \mathrm{~S} 61(3)$ of the NHA.

35 Mcquoid-Mason "Human Tissue and Organ Transplant Provisions: Chapter 8 of the National Health Act and its Regulations, in Effect from March 2012 - What Doctors Must Know" 2012 102(9) SAMJ 734-735.

$36 \mathrm{~S} 61(5)$ of the NHA.

37 This was not previously defined in the repealed Human Tissue Act.

38 GN R180 in GG 35099 of 2012-03-02.

$39 \mathrm{~S} 62(2)$ of the NHA.

40 62(1) of the NHA.

S 4 of the Wills Act 7 of 1953.

S 1 of the Wills Act 7 of 1953.

Ss 62(1) and 61(1) and (2) of the NHA.

Mcquoid-Mason 2012 SAMJ 734-735); GN R180 in GG 35099 of 2012-03-02.

45 GN R180 in GG 35099 of 2012-03-02.

46 GN R180 in GG 35099 of 2012-03-02. 
new will or document. ${ }^{47}$ Slabbert reflects that new statutes such as the Protection of Personal Information Act ${ }^{48}$ should not hinder the organ donation process. ${ }^{49}$

There are two approaches to organ donation - namely, the opt-in system and the opt-out system. Currently, South African organ donation is based on the opt-in system. ${ }^{50}$ This requires explicit consent to harvest organs from the family of a deceased person. There are an increasing number of countries adopting the opt-out system. This means that every person after death is presumed to be a potential organ donor unless the patient has indicated otherwise during his or her lifetime. Many countries adopt "soft" opt-out systems, where family members can decline organ donation on behalf of the deceased person, if they so wish. ${ }^{51}$

However, implementation of the opt-out systems does not always increase organ donation rates. ${ }^{52}$ In fact, Etheredge and co-workers studying attitudes to organ donation among South Africans felt that an opt-out system would have a negative effect on organ donation rates in South Africa. ${ }^{53}$ Etheredge postulates that the opt-out system of presumed consent is not consistent with South African law. ${ }^{54}$ Furthermore, religious and cultural freedom as well as the concept of informed consent would be compromised. ${ }^{55}$ Slabbert and Venter reiterate that it is not the opt-in organ procurement system in South Africa that is the problem. ${ }^{56}$ At present, the majority of researchers believe that an opt-out system is not feasible in South Africa, as the population lacks sufficient information about organ donation to make an informed decision. ${ }^{57}$

\section{ISLAMIC LAW (SHARI'AH) AND ORGAN DONATION}

\section{Background and sources of Islamic Law}

Muslims believe that the Qur'ān is the divine word of God (Allah) and was revealed to the Prophet Muhammad (born 571, died 632), whom they believe is the last messenger of God. ${ }^{58}$ Islam is a complete way of life and

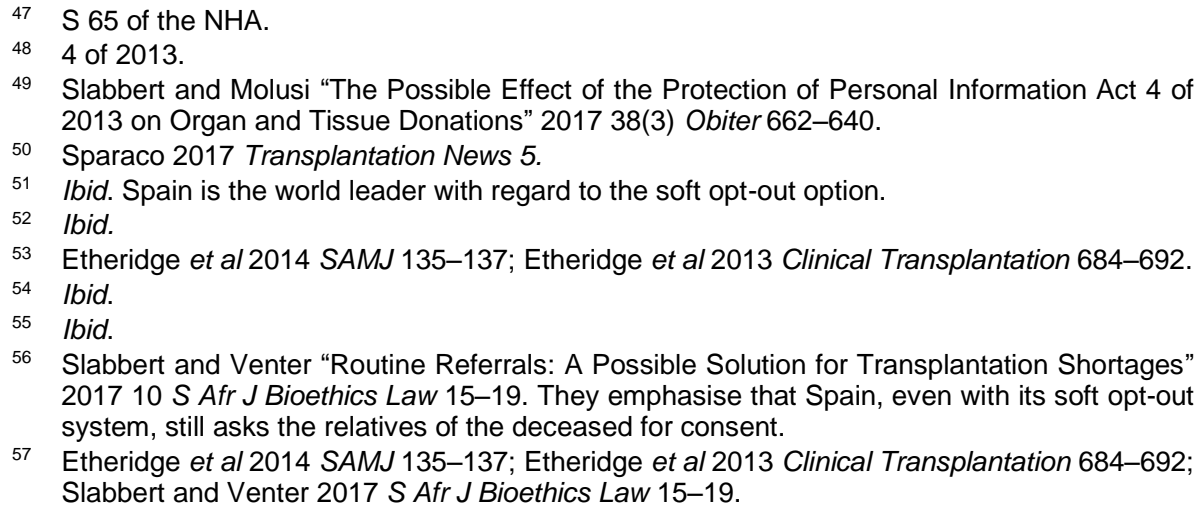


encompasses the spiritual together with the mundane activities of life.59 Although their core beliefs are the same, Muslims can be divided politically into two groups: the majority (about 95 per cent) are Sunni, and the remainder are Shī ah. ${ }^{60}$ Iran is the only Shĩ ah Muslim country.

Shariah (Islamic law) and figh (Islamic jurisprudence) provide the conceptual basis upon which all Islamic legal principles are founded. Sharīah is laid out in the Qur'ān, revealed by God to Prophet Muhammad and the Sunnah (verbal commands and practices of Prophet Muhammad) as recorded in the Hadith (compilations of the Sunnah). ${ }^{61}$ Muslims maintain that all laws are derived from careful study of these primary sources and there can be no new addition to them, except in interpretation. ${ }^{62}$ Islamic jurisprudence is known as figh and is the human understanding and interpretation of the Sharīah.63 An Islamic jurisprudential scholar (faqīh), after study of the law, will determine whether an action is lawful (halāl) or unlawful (harām). ${ }^{64}$ In addition to the two primary sources (the Qur'ān and Sunnah/Hadith of Prophet Muhammad), there are two secondary sources. These are Islamic scholarly consensus (ijmā') and legal reasoning by analogy (qiyās).

When a scholar attempts to find an existing legal principle or develop a new one, the sources need to be carefully examined, and have to be consulted in a particular order. The first source needing to be considered is the Qur'ān. Sharīah is principally based on the Holy Qur'ān. ${ }^{65}$ About 500 verses in the Qur'ān have legal content. These cover a broad range of issues, including personal matters (charity and fasting), family matters (marriage, divorce and inheritance), commercial transactions (sales, leases and interest), crimes and penalties, justice, equality, evidence and citizen's rights and duties. ${ }^{66}$ The Qur'ān expresses the law both in legal and ethical principles. ${ }^{67}$

The next source is the Sunnah or Hadith. Sunnah (literally "well-trodden path") is based on the practices of Prophet Muhammad and constitutes Islamic traditions. ${ }^{68}$ Books of Hadith (literally "to report") are the collections of words and deeds of the Prophet Muhammad that were recorded both verbally and in writing by his companions. ${ }^{69}$ Hadith are based on Prophet Muhammad's own life and are the biographical basis of Sharīah. The

59 Albar "Organ Transplantation: A Sunni Islamic Perspective" 201223 Saudi J Kidney Dis Transpl 817-822.

60 Goodarzi "Tissue and Organ Donation and Transplantation in Iran" 201516 Cell Tissue Bank 295-301.

61 Ahadith.co.uk "Hadith Search Engine" http://ahadith.co.uk/search (accessed 2019-04-12); Sheikh 2017 J Int L Islamic L 30-44.

62 Ibid.

63 Ibid.

64 Ibid.

65 Ali The Holy Qur'an: Test, Translation and Commentary (1984); Ahadith.co.uk http://ahadith.co.uk/search.

66 Kamali "Law and Society: The Interplay of Revelation and Reason" in Esposito (ed) The Oxford History of Islam (1999) 107.

67 Sheikh $2017 \mathrm{~J}$ Int L Islamic L 30-44.

68 Ahadith.co.uk http://ahadith.co.uk/search.

69 Sheikh $2017 \mathrm{~J}$ Int L Islamic L 30-44. 
Sunnah is the entire system of religious, legal and social obligations derived from the Hadith. ${ }^{70}$ The categorisation and authentication of Hadith is an arduous science and is beyond the scope of this article.

The third source is ljmā', which is the consensus of legal opinion by jurists on religious and legal issues. ${ }^{71}$ Legitimacy of scholarly decisions is achieved by consensus within the Muslim community. Ijmā' is an important source of Sharīah in Islam. In a Hadith, Prophet Muhammad was reported to say: "My people (the Muslim ummah) will never agree upon an error."72 The final source is Qiyās, which are strict analogical deductions derived from the Qur'ān, Sunnah and Hadīth, and Ijmā ' ${ }^{73}$ Islamic scholars use Qiyās to formulate legal decisions on matters not directly addressed in the Qur'an, Sunnah/Hadith and by ljmā' - for example, organ donation. Qiyās allow Islamic scholars and jurists to develop a principle on an issue not decided earlier, thus ensuring that Sharī ah remains dynamic and equally applicable to the present day. ${ }^{74}$

Where the sources are silent on an issue, a legal principle can be developed through ljmā (consensus of jurists) or Qiyās (analogical deduction). Jurists have arrived at an Islamic principle on organ donation through considered examination of the sources and the objectives of Islamic law and this is set out below.

\section{Legal principle of organ donation in Islamic law}

Organ transplantation per se is not addressed in the two primary sources of Sharī ah (the Qur'än and Sunnah)..$^{75}$ It is in the secondary sources that we find jurisprudential legal principle on organ donation in Islam. The Muslim jurists in favour of organ donation base their arguments on the objectives of Sharīah. The three objectives discussed below are Al Mașlahah (greater public welfare and interest), Al İhār (Altruism), and the directive to seek medical treatment.

The concept of greater public welfare is extremely important in the Sharīah and is a principal component of Islamic jurisprudence. ${ }^{76}$ When considering this objective, three Islamic judicial rules apply. ${ }^{77}$ First is the principle of necessity (darūrah) (since necessity makes the unlawful permissible). Secondly, when two conflicting interests arise, the one that derives greater benefit takes precedence. Finally, the lesser of two evils is selected.

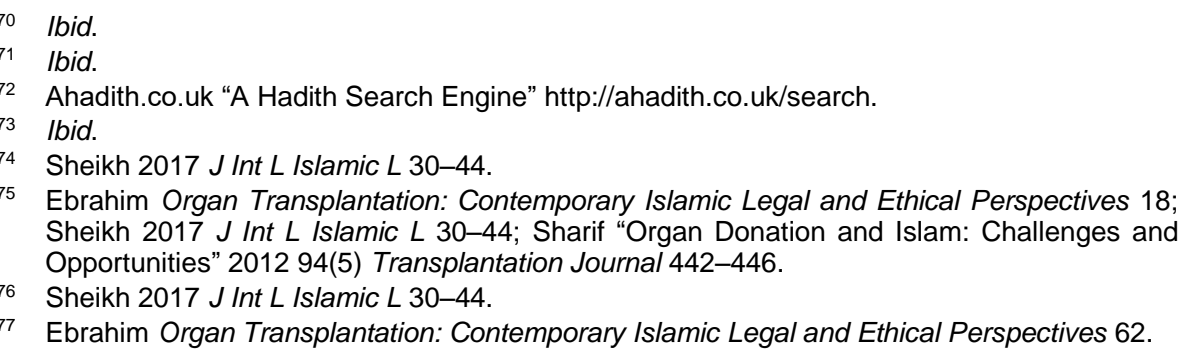

Ebrahim Organ Transplantation: Contemporary Islamic Legal and Ethical Perspectives 18; Sheikh 2017 J Int L Islamic L 30-44; Sharif "Organ Donation and Islam: Challenges and Opportunities" 2012 94(5) Transplantation Journal 442-446.

6 Sheikh 2017 J Int L Islamic L 30-44.

77 Ebrahim Organ Transplantation: Contemporary Islamic Legal and Ethical Perspectives 62. 
The concept of Mașlahah is based on the doctrines of necessity and equitable consideration. ${ }^{78}$ In terms of necessity, the Qur'ān says in Sürat Baqarah, chapter 2, verse 173 (2:173):79

"He hath only forbidden you dead meat, and blood, and the flesh of swine, and that on which any other name hath been invoked besides that of Allah. But if one is forced by necessity, without willful disobedience, nor transgressing due limits, then is he guiltless. For Allah is Oft-forgiving Most Merciful."

Thus, in the face of necessity the unlawful becomes lawful.

Furthermore, Ebrahim explains that, if the general gain outweighs the negative aspects of an action, the action would be allowed. ${ }^{80}$ In this context, Shari ${ }^{2}$ h would allow the cutting of the belly of a dead pregnant woman in order to save the life of the baby. Thus, the rights of the living supersede consideration of the dead. ${ }^{81}$ Similarly, Ebrahim explains that Sharīah would allow the cutting of the belly of a deceased person who swallowed a valuable object (for example, a diamond), in order that it may be returned to the rightful owner. The explanation for this is that, even if the valuable object belonged to the deceased, the heirs would be in a position to benefit from it. ${ }^{82}$ Ebrahim argues that, following the same line of reasoning, it would be justifiable to retrieve a deceased person's organ, for the purposes of transplanting it into a living person, thereby benefiting the recipient. ${ }^{83}$

Furthermore, in accordance with the principle of equity, lesser harm is tolerated if it leads to a greater good for the community. According to this principle, Sheikh believes that if one person dies because an organ cannot be found, all of society is harmed. ${ }^{84}$ The Qur'ān emphasises the sanctity of human life in chapter 5 , verse $32(5: 32): 85$

"If anyone slays a human being unless it be (in punishment) for murder or for spreading corruption on earth - it shall be as if he had slain the whole of mankind; whereas if anyone saves a life, it shall be as if he had saved the life of all mankind."

Nevertheless, Ebrahim and others caution that the following conditions must be present for transplantation to take place: 86

(a) Transplantation must be the only means of treatment for the patient in need of the organ.

(b) The degree of success of the procedure must be relatively high.

\footnotetext{
Sheikh $2017 \mathrm{~J}$ Int L Islamic L 30-44.

9 Ali The Holy Qur'an: Test, Translation and Commentary; Ahadith.co.uk http://ahadith.co.uk/search.

80 Ebrahim Organ Transplantation: Contemporary Islamic Legal and Ethical Perspectives 63.

81 Ibid.

82 Ibid.

33 Ibid.

84 Sheikh 2017 J Int L Islamic L 30-44.

85 Ali The Holy Qur'an: Test, Translation and Commentary; Ahadith.co.uk http://ahadith.co.uk/search.

86 Ebrahim Organ Transplantation: Contemporary Islamic Legal and Ethical Perspectives 64 Sheikh $2017 \mathrm{~J}$ Int L Islamic L 30-44.
} 
(c) The consent of the owner of the organ or the heirs must have been obtained.

(d) Death must have been fully established.

(e) The recipient must have been informed of the operation and its implications.

The second objective of Sharīah is Al IThār (Altruism). The Qur'ān and the Sunnah both exhort Muslims to do good deeds and to cooperate with one another in acts of kindness. The Qur'anic imperative in chapter 5, verse 215 $(5: 215)$ is: ${ }^{87}$

"Help you one another in righteousness and piety."

The Qur'ān admonishes believers in chapter 59, verse 9 (59:9) to:88

"show their affection to such as came to them for refuge, and entertain no desire in their hearts for things given to the (latter), but give them preference over themselves, even though poverty was their (own lot). And those save from the covetousness of their own souls, they are the ones that achieve prosperity."

Again, in chapter 3, verse 92 (3:92), the Qur'ān addresses the believers, stating: 89

"by no means shall ye attain righteousness unless ye give (freely) of that which ye love."

As for the Sunnah, Prophet Muhammad is reported to have said:

"None of you truly believe till he wishes for his brother what he wishes for himself"90

and

"whoever helps another, will be granted help in the hereafter."91

Islamic scholars use a combination of the above authoritative directives to promote organ donation under the principle of altruism. Donation of an organ could be considered as an act of charity (sadaqah). ${ }^{92}$ Such acts of charity are not confined to Muslims only. Prophet Muhammad exhorted his followers to love all humanity. Once, when Prophet Muhammad stood in veneration of the passing funeral of a Jewish man at a time when Jews were waging war against him and Islam, one of his companions exclaimed, "It is the funeral of a Jew." The Prophet answered, "Is it not a human soul?"93

87 Ali The Holy Qur'an: Test, Translation and Commentary; Ahadith.co.uk http://ahadith.co.uk/search

88 Ibid.

89 lbid.

90 Ahadith.co.uk http://ahadith.co.uk/search.

91 Ibid.

92 Zahidul Islam "Organ Donation and Transplantation Issues in Islam and Present Situation" 201422 Journal of Law, Policy and Globalization 99-103.

93 Ahadith.co.uk http://ahadith.co.uk/search. 
The Prophet ordered Muslims to be compassionate to all human beings. He declared:

"All mankind is the family of Allah. Those who best serve his family are best loved by God." 94

However, all scholars agree that a vital organ, such as the heart, cannot be donated by a living donor, as this would be tantamount to suicide. ${ }^{95}$

The third objective of Sharīah is the directive to seek medical treatment. Prophet Muhammad has exhorted his followers to seek medical treatment. ${ }^{96}$

"Make use of medical treatment, for Allah has not made a disease without a remedy for it."

Thus, using the sources cited above, individual jurists and scholars declare organ donation to be permitted in Islam, subject to certain conditions. There are also collective resolutions (Qarārāt) on organ donation, as discussed below.

\section{Islamic organisational judicial resolutions (Qarārāt) on organ donation}

A qarar is a collective resolution of Muslim scholars that is binding upon the Muslim community. Shìah scholars were the first to sanction organ donation. ${ }^{97}$ In 1995, the Council of the Islamic Figh Academy of the Muslim World League, Makkah, Saudi Arabia resolved that organ donation was permissible, that it does not violate the dignity of the body of the donor, and that it is a praiseworthy act, as long as the following conditions are met: ${ }^{98}$

(a) The donor's life is not harmed.

(b) The donor voluntarily consents without coercion.

(c) The procedure is the only medical means to alleviate the plight of the patient.

(d) The success of transplantation is relatively high.

In 1988, the Council of the Fiqh Academy of the Organization of Islamic Conference, Jeddah, Saudi Arabia concurred with the above fatwa. ${ }^{99}$ The Supreme Council of 'Ulamā', in Riyadh, Saudi Arabia, sanctioned organ donation as did the Grand Mufti of Egypt. ${ }^{100}$ Positive rulings on organ donation and transplantation were issued in Egypt (1966), Malaysia (1969), Algeria (1972), Jordan (1977), and Kuwait (1979). ${ }^{101}$ In the United Kingdom, the Muslim Law Council has encouraged Muslims to carry organ donation

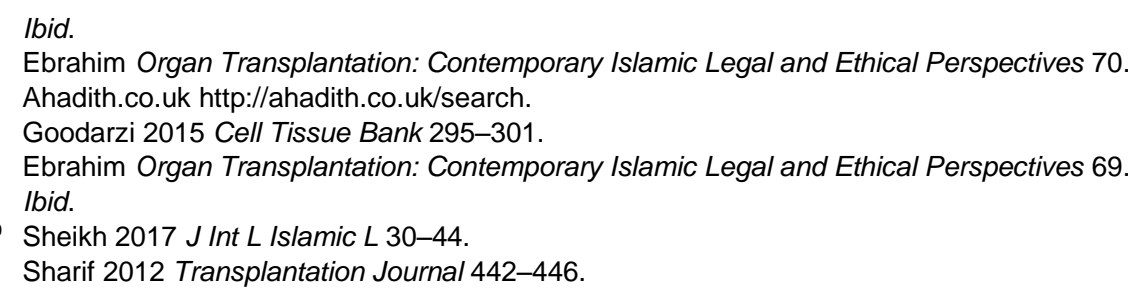


cards. ${ }^{102}$ Approval for organ donation from unidentified cadavers, provided there are no next of kin, was issued by the Grand Mufti of Egypt; approval from a magistrate was required. ${ }^{103}$ The Islamic Figh Academy of the Organization of Islamic Conference, Jeddah, Saudi Arabia made a similar positive ruling on the harvesting of organs from unidentified cadavers, or where relatives could not be found. In this case, approval from the leaders of the Muslim community was required. ${ }^{104}$

However, all Islamic scholars agree that certain restrictions apply to organ donation (discussed above), and that a single vital organ, such as a heart, cannot be donated, even with consent of the donor, as this would be tantamount to suicide. 105

Although virtually all Islamic scholars and councils across the Muslim world have issued approval for organ donation from both living and cadaveric donors, Muslims are still very hesitant to engage in the practice. Currently, issues such as harvesting of organs from anencephalic babies and embryonic stem cell transplants are being debated by these bodies, but the information and resolutions do not seem to filter down to Muslim communities. ${ }^{106}$

\section{Islamic law and the opt-in versus opt-out system}

The opt-in and opt-out systems were discussed under heading 2 above. All Islamic scholars are agreed that explicit consent by the living donor or the deceased's relatives is imperative. ${ }^{107}$ There is no exception to this rule, unless the deceased is unidentified or relatives cannot be found, but in this case, consent will need to be obtained from a magistrate. ${ }^{108}$ Thus, Șharīah strictly adheres to the opt-in system of explicit consent; opt-out and even soft opt-out options are not seen to be consistent with the tenets of Islamic law.

\section{Islamic law and the sale of organs}

The vast majority of Sunni Islamic jurists concur that the sale of organs is forbidden. ${ }^{109}$ Such a sale would be deemed null and void (bāttil), as one cannot sell that which one does not own: God is the owner of the body which is held by a person as a trust or aminah. Furthermore, the selling of an organ is akin to selling a person. In support of this resolution, Islamic scholars quote Prophet Munammad, who is reported to have said:

102 Ibid.

103 Albar 2012 Saudi J Kidney Dis Transp/ 817-822.

104 Zahidul Islam 2014 Journal of Law, Policy and Globalization 99-103.

105 Ebrahim Organ Transplantation: Contemporary Islamic Legal and Ethical Perspectives 69.

106 Albar 2012 Saudi J Kidney Dis Transp/ 817-822.

107 Ebrahim Organ Transplantation: Contemporary Islamic Legal and Ethical Perspectives 76.

108 Albar 2012 Saudi J Kidney Dis Transpl 817-822; Zahidul Islam 2014 Journal of Law, Policy and Globalization 99-103.

109 Sheikh 2017 J Int L Islamic L 30-44; Natour and Fishman "Islamic Sunni Mainstream Opinions on Compensation of Organ Donors" 2011 2(2) Rambam Maimonides Medical Journal 46-59. 
"There are three categories of people against whom I shall myself testify against on the day of judgement. Of those three, one is he who enslaves a free man, then sells him, and eats this money." 110

This strong warning by Prophet Muhammad is regarded as pivotal in concluding that organ sales are not permissible in Islamic law. Shì ah Islamic scholars, however, support the sale of organs by a living donor or by the deceased donor's relatives through the concept of "divine consent". ${ }^{111}$ Divine consent requires that an act be done with a sincere intention, confirmed by reason and divine revelations that bring about peace, while preserving dignity and autonomy. In Iran, the only Shì ah Muslim country, a fatwā by the Ayatollah sanctioning the sale of organs paved the way for legislation of a state-run compensated organ procurement system. ${ }^{112}$

\section{Islamic law and the bequest of organs}

Al-Wașiyah is the Arabic equivalent of the last will and testament. ${ }^{113}$ Muslims are encouraged to draw up a will during their lifetime. In chapter 5 , verse 106, (5:106), the Qur'ān says:

"O you who believe! When death approaches any of you, (take) witnesses among yourselves when making bequests - two just men of your own (brotherhood), or others from outside if you are on a journey when the affliction of death befalls you."114

Since the Qur'ān is a primary source of Islamic law, it means that this legal principle should not be taken lightly. Muslims should implement it accordingly.

Likewise, Prophet Muhammad emphasised the importance of drawing up a will. He was reported to have said:

"It is not right for any Muslim person, who has anything to bequeath, that he may pass even two nights without having his last will and testament written and kept ready with him."115

The Sunnah (traditions of the Prophet Muhammad) too is regarded as a primary source. The idea of making a will is therefore important as it is encouraged in both the Qur'ān and the Sunnah.

Despite the position in Islamic law encouraging Muslims to provide for in a will, Ebrahim cautions that there are certain restrictions in the Sharīah as to what one may will. ${ }^{116}$ For example, one cannot bequeath one's wealth or possessions as one wishes, as these bequests are governed by specific

110 Ahadith.co.uk http://ahadith.co.uk/search.

111 Larijani, Zahedi and Taheri "Ethical and Legal Aspects of Organ Transplantation in Iran" 2004 36(15) Transplantation Proceedings 1241-1244; Sheikh 2017 J Int L Islamic L 30-44.

112 Denghan "Ethical Challenges of Kidney Sale: A Review of Three Major Assumptions Based on the Theories of Tabatabat" 201961 J Forensic Leg Med 27-33.

113 Ebrahim 2000 Med Law 147-160.

114 Ali The Holy Qur'an: Test, Translation and Commentary; Ahadith.co.uk http://ahadith.co.uk/search.

115 Ahadith.co.uk http://ahadith.co.uk/search.

116 Ebrahim Organ Transplantation: Contemporary Islamic Legal and Ethical Perspectives 73. 
Shari ah directives that determine how one's wealth and possessions are to be distributed after death. ${ }^{117}$ Legal heirs will receive proportionate shares as laid down by Shari ah, and this is not dependent upon the will or any other instruction of the deceased. ${ }^{118}$ A "living will" that stipulates that life-saving measures should be withdrawn in the event of severe illness has no legal status in the Shari ah, as it is considered a crime in Islam to hasten death. ${ }^{119}$ In summary, a will cannot contradict the broad teachings of the Qur'ān and Sunnah.

With regard to bequeathing an organ or organs in a will while still alive, there have been several religious decrees (fatwas) sanctioning this. In 1982, the Grand Mufti of Egypt, Gãd Al Haq sanctioned the bequest of organs in a will or testament. ${ }^{120}$ The Saudi Grand 'Ulamā' Fatwa No. 99, 1982 also declared the permissibility of bequeathing organs in a will. ${ }^{121}$ The Fatwa Committee of Kuwait issued a similar ruling. ${ }^{122}$ Ebrahim, writing on the living will in the light of Islamic jurisprudence, was also of the view that bequeathing one's organs in a will is permissible. ${ }^{123}$

\section{COMPARATIVE ANALYSIS OF SOUTH AFRICAN AND ISLAMIC LAW}

There are fundamental differences between the general laws that comprise each of the legal systems. First, Muslims regard Islamic law as the ultimate, God-given, immutable law; unlike South African law, they believe it is not subject to change. ${ }^{124}$ Secondly, Islamic law is all-encompassing and concerns itself not only with legal matters, but also with moral, spiritual and personal matters. In contrast, South African law confines itself to legal matters. ${ }^{125}$ Thirdly, unlike South African law, which is drafted in Parliament, Islamic law is not presently as structured and codified, and is compiled by Muslim jurists within each Muslim country. Lastly, and perhaps most importantly, Ebrahim explains that sources of Sharīah, strictly speaking, are not legal documents, but offer a set of Islamic legal principles and moral and ethical guidelines, from which legal principles can be inferred. ${ }^{126}$ It is, therefore apparent that there will be many minor differences between South African and Islamic law that are inherent to each legal system. The focus below is on the overwhelmingly broad general consensus as opposed to the minor divergence.

The broad similarities between Islamic and South African law are startling. Both systems permit living and cadaveric organ donation. Both systems recognise brain death as death. Thus, in the NHA, brain death is defined as

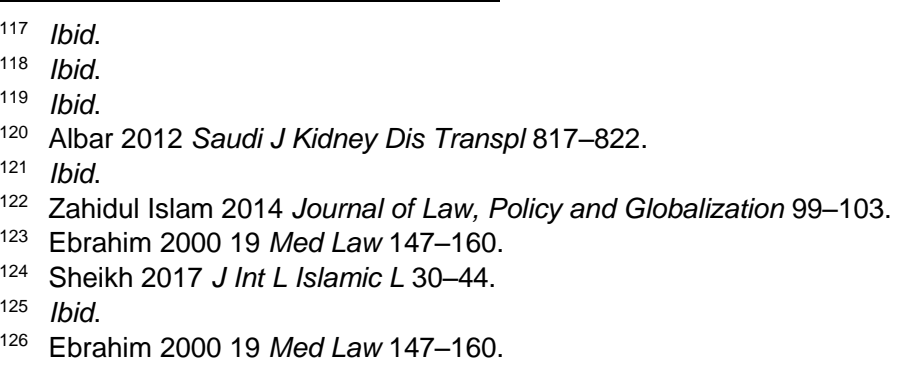


death. ${ }^{127}$ At the third International Conference of Islamic Jurists (Amman, Jordan, 1986), Fatwā No. 5 equated brain death with cardiac and respiratory death. ${ }^{128}$ Death in Islam is the departure of the soul. However, as this cannot be identified, the medical signs of death are acceptable. ${ }^{129}$ Both the Muslim Law Council of $U$, and the Islamic Medical Association of North America from the USA equate brain death with death. ${ }^{130}$ Both Islamic and South African law stipulates that brain death (death) needs to be confirmed by medical practitioners. South African law is more specific; the regulations stipulate that the diagnosis of brain death needs to be made by two doctors, one of whom must have been qualified for more than five years and neither of whom may be members of the transplant team. ${ }^{131}$ In Islamic law, death should be confirmed by doctors of "upright character". ${ }^{132}$

Both systems forbid the donation of a single vital organ from a living donor. South African law stipulates that a person under the age of 18 years may not donate tissue that is not replaceable by natural means, while Islamic law directs that there must be no imminent danger to the life of the donor. ${ }^{133}$ Both systems allow for the harvesting of organs from an unidentified cadaver or where the relatives cannot be found. In South African law, this must be approved by the Director-General of Health, and in Islamic law, by a magistrate or leaders of the Muslim community. ${ }^{134}$ Both South African and Islamic law require explicit positive consent from the living donor for organ donation, or from the relatives of the deceased. Both South African and the Sunni Islamic law forbid the sale of organs or compensation of the donor (other than medical expenses and travel costs).

Bequeathing organs in a will, testament or document is permissible both in South African and Islamic law. In Islamic law, drawing up a will while alive is a divine injunction and enjoined by Prophet Muhammad. Although an oral statement in the presence of competent witnesses is acceptable, both South African and Islamic law encourage a written document signed in the presence of appropriate witnesses.

Thus, there is complete consensus on bequeathing organs in South African and Islamic law. There is, however, a striking difference between Shi'ah Islamic law (minority in the Muslim world) and South African law since the sale of organs and compensation of the donor is permitted by Shi'ah Islamic scholars, while this is considered an offence in South African law. ${ }^{135}$

\footnotetext{
$\mathrm{S} 1$ of the $\mathrm{NHA}$

128 Albar 2012 Saudi J Kidney Dis Transp/ 817-822.

129 Ibid.

130 Athar and Fadel "Islamic Medical Ethics: The IMANA Perspective" 2005 37(1) Journal of Islamic Medical Association of North America 32-41; Sharif 2012 Transplantation Journal 442-446.

131 GN R180 in GG 35099 of 2012-03-02.

132 Ebrahim Organ Transplantation: Contemporary Islamic Legal and Ethical Perspectives 93.

${ }_{133} \mathrm{~S} 56(2)$ of the NHA; Ebrahim Organ Transplantation: Contemporary Islamic Legal and Ethical Perspectives 64.

134 S 62(3) of the NHA; Albar 2012 Saudi J Kidney Dis Transp/ 817-822; Zahidul Islam 2014 Journal of Law, Policy and Globalization 99-103.

135 S 60 of the NHA; Goodarzi 2015 Cell Tissue Bank 295-301.
} 
Iran thus has a national organ procurement agency, and South Africa does not. ${ }^{136}$

\section{CONCLUSION AND RECOMMENDATIONS}

Apart from very minor differences inherent in South African and mainstream Islamic law (Shari'ah) respectively, there is near-total consensus in the two legal systems with regard to living and cadaveric organ donation. Iran, which is the sole Shiīah Muslim country, diverges from South African law in allowing the sale of organs and compensation of donors.

Many Muslims believe that bequeathing organs is forbidden in Islamic law. ${ }^{137}$ On the contrary, Islamic law not only permits the bequest of organs, but encourages it as an altruistic act of charity and a commendable gesture for the benefit of the greater community. ${ }^{138}$ This article contributes to the research literature available to professionals such as doctors and lawyers, placing them in a position to share this knowledge, with a view to increasing organ donation rates among Muslims in South Africa.

It must be noted that various interventions aimed at different levels are required in order to improve organ donation rates in South Africa. Slabbert and others have suggested a number of legislative reforms. ${ }^{139}$ In addition, Moosa proposes improving resources for organ transplantation (increased facilities for the care of brain-dead donors, dedicated theatre time, improving the skills pools, extending the role of the transplant coordinator and promoting organ donation among healthcare professionals). ${ }^{140}$ South Africa has a two-tiered health system, a robust private healthcare sector and an ailing public sector with limited resources and long waiting lists. ${ }^{141}$ Moosa emphasises the role of public-private collaborative initiatives to promote organ donation. ${ }^{142}$

136 Mahdavi-Mazde, Rouchi, Norouzi and Ahrabi "Renal Replacement Therapy in Iran" 2007 5(2) Urology Journal 66-70.

137 Tumin, Noh, Satar and Chong "Organ Donation in Muslim Countries: The Case of Malaysia" 201318 Annals of Transplantation 671-676.

138 Zahidul Islam 2014 Journal of Law, Policy and Globalization 99-103.

139 Slabbert "Combat Organ Trafficking: Reward the Donor or Regulate Sales" 2008 73(1) Koers 75-99; Slabbert and Venter 2017 S Afr J Bioethics Law 15-19; Venter and Slabbert "Rewarding a Living Kidney Donor: A Comparison Between South Africa, Singapore and Iran" 2013 34(2) Obiter 185-199; Slabbert and Oosthuizen "Establishing a Market for Human Organs in South Africa Part 1: A Proposal" 2007 28(1) Obiter 44-69; Slabbert and Oosthuizen 'Establishing a Market for Human Organs in South Africa Part 2: Shortcomings in Legislation and the Current System of Organ Procurement' 2007 28(2) Obiter 304-323; Slabbert "The Law as an Obstacle in Solid Organ Donations and Transplantations" 2018 8(1) THRHR 70-84; Slabbert "One Heart, Two Patients: Who Gets a Donor Organ?" 2009 Stell L R 1 124-138; Slabbert "Ethics, Justice, and the Sale of Kidney for Transplantation Purposes" 2010 13(2) PER/PELS 77-105; Venter "A Selection of Constitutional Perspectives on Human Kidney Sales" 2013 16(1) PER/PELJ 352-403.

140 Ibid.

141 Harrichandparsad, Nadvi, Naidoo and Mahomed "A Tale of Two Cities: A Snapshot Survey of Neurosurgical Procedures Performed in Public and Private Sectors in Ethekwini" 2019 57(2) South African Journal of Surgery 61-64.

142 Moosa "The State of Kidney Transplantation in South Africa" 2019 109(4) SAMJ 235-240. 
To improve organ donation rates in South Africa, perhaps the most beneficial initiative is to change attitudes to organ donation. ${ }^{143}$ Public campaigns to provide accurate information on organ donation need to be employed, both for the general South African public and also in the Muslim community. Albar writes compellingly on the need to campaign for organ donation at mosques. ${ }^{144} \mathrm{He}$ believes that the moral code of Islam encourages organ donation, and campaigns should be directed at Muslims attending mosques. ${ }^{145}$

It is our belief that this study, which has identified a broad consensus in South African and Islamic law on the issues of living and cadaveric organ donation, will place professionals in a knowledgeable position to provide informed advice to their client base. It is also envisaged that the knowledge disseminated from this article could be used to develop broad educational campaigns aimed at the public generally and the Muslim community specifically, which will in turn inspire the public and Muslims in South Africa to actively engage in organ donation practices.

143 Ibid.

144 Albar 2012 Saudi J Kidney Dis Transp/ 817-822.

145 Ibid. 